Article

\title{
Deposition of Copper on Poly(Lactide) Non-Woven Fabrics by Magnetron Sputtering-Fabrication of New Multi-Functional, Antimicrobial Composite Materials
}

\author{
Marcin H. Kudzin * (D) Zdzisława Mrozińska, Anna Kaczmarek and Agnieszka Lisiak-Kucińska \\ Lukasiewicz Research Network-Textile Research Institute, Brzezinska 5/15, 92-103 Lodz, Poland; \\ zmrozinska@iw.lodz.pl (Z.M.); akaczmarek@iw.lodz.pl (A.K.); alisiak@iw.lodz.pl (A.L.-K.) \\ * Correspondence: kudzin@iw.lodz.pl; Tel.: +48-42-61-63-121
}

Received: 21 July 2020; Accepted: 3 September 2020; Published: 8 September 2020

\begin{abstract}
The paper presents the method of synthesis; physico-technical and biological characterization of a new composite material (PLA- $\mathrm{Cu}^{0}$ ) obtained by sputter deposition of copper on melt-blown poly(lactide) (PLA) non-woven fabrics. The analysis of these biofunctionalized non-woven fabrics included: ultraviolet/visible (UV/VIS) transmittance; scanning electron microscopy/energy-dispersive spectroscopy (SEM/EDS); attenuated total reflection Fourier transform infrared (ATR-FTIR) spectroscopy; ability to block UV radiation; filtration parameters (air permeability); and tensile testing. The functionalized non-woven composite materials were subjected to antimicrobial tests against colonies of Gram-negative (Escherichia coli), Gram-positive (Staphylococcus aureus) bacteria and antifungal tests against the Chaetomium globosum fungal mould species. The antibacterial and antifungal activity of $\mathrm{PLA}-\mathrm{Cu}^{0}$ suggests potential applications as an antimicrobial material.
\end{abstract}

Keywords: poly(lactide); nonwovens; melt-blown; antimicrobial material; polyamides; copper; magnetron sputtering; antibacterial activity; composite

\section{Introduction}

Poly(lactide) (PLA) is a multifunctional application polymer widely engaged in various biomedical applications, including controlled drug delivery, wound healing, tissue engineering and regenerative medicine [1-8].

Substantial importance in this field is played by PLA composites equipped with antibacterial additivities, in the majority organic bactericides (e.g., ampicillin [9] chlorhexidine [10,11], ciprofloxacin [12,13], doxycyclin [14], gentamycin [15], oflaxin and vancomycin [16], triclosan [17-19], and/or curcumin [20], etc.). Due to an established role of metal nanoparticles in medicine [21-33], the group of increasing importance is PLA-inorganic hybrids [34], due to their high antibacterial efficiency, simplicity and also low cost of technological preparation.

Some of the representative applications of antibacterial PLA composites are listed in Table 1. 
Table 1. Representative application of antibacterial poly(lactide) (PLA) composites.

\begin{tabular}{|c|c|c|c|}
\hline No & PLA Composite & Action/Application & Lit. \\
\hline \multicolumn{4}{|c|}{ 1. PLA/ANTIBIOTICS/DRUGS } \\
\hline 1.1 & PLA/AMP & antibacterial activity (against A.c., E.f., F.n. and P.g.) & [9] \\
\hline 1.2 & PLA/CHX & $\begin{array}{l}\text { antibacterial activity against both } \mathrm{G}(+) \text { and } \mathrm{G}(-) \text { bacteria; the } \\
\text { treatment of persistent infections in medicine and dentistry }\end{array}$ & {$[10,11]$} \\
\hline 1.3 & PLA/CPX & potential application as a drug delivery system & {$[12,13]$} \\
\hline 1.4 & PLA/DOX & chronic wound treatment & [14] \\
\hline 1.5 & PLA/GM & $\begin{array}{l}\text { delivery platforms with strong and timing controllable } \\
\text { antibacterial properties (against E.c.) }\end{array}$ & [15] \\
\hline 1.6 & $\begin{array}{l}\text { PLA/OFL; } \\
\text { PLA/VAN }\end{array}$ & $\begin{array}{c}\text { antibacterial activity (against E.c. and MRSA), possible } \\
\text { alternative drug against pathogenic bacterial strains of public } \\
\text { health interest }\end{array}$ & [16] \\
\hline 1.7 & PLA/Tric & $\begin{array}{c}\text { antibacterial activity against } \mathrm{G}(+) \text { and } \mathrm{G}(-) \text { bacteria; a good } \\
\text { osteoblast cell attachment on the composite scaffolds; a suitable } \\
\text { composite for the bone tissue engineering and } \\
\text { medical applications }\end{array}$ & {$[11,17-19]$} \\
\hline 1.8 & PLA/Cur & antibacterial (against S.a.) and anticoagulant activity & [20] \\
\hline \multicolumn{4}{|c|}{ 2. PLA/IONS/MNPS [21-27] } \\
\hline \multirow{3}{*}{2.1} & \multirow{3}{*}{ PLA/Ag+ } & antibacterial activity (against S.a., E.c.); medical dressings & [28] \\
\hline & & $\begin{array}{l}\text { Antibacterial properties (against E.c. and MRSA); potentantial } \\
\text { bacterialwound-dressing materials }\end{array}$ & [29] \\
\hline & & $\begin{array}{l}\text { Antibacterial polylactide materials (against S.en.) of significant } \\
\text { potential in coating applications }\end{array}$ & {$[30]$} \\
\hline 2.2 & $\mathrm{PLA} / \mathrm{CuSiO}_{3}$ & $\begin{array}{l}\text { very good antibacterial activity (against E.c., S.a.) and antifungal } \\
\text { properties (against C.a.) }\end{array}$ & [31] \\
\hline 2.3 & $\begin{array}{l}\text { PLA/ZnO } \\
\text { (surface or } \\
\text { bulk deposited) }\end{array}$ & antimicrobial activity (against $S . a$.) & [32] \\
\hline 2.4 & $\mathrm{PLA} / \mathrm{TiO}_{2}$ & no mammalian cell toxicity, bactericidal activity & [33] \\
\hline \multicolumn{4}{|c|}{$\begin{array}{l}\text { Antibiotics/drugs: AMP—ampicillin; CHX-chlorhexidine; CPX—ciprofloxacin; Cur-curcumin; DOX—doxycycline; } \\
\text { GM-gentamycin; OFL—ofloxacin; TCS (Tric)—triclosan; VAN—vancomycin. Bacteria: A.c.-Actinomycetemcomitans; } \\
\text { E.f.-Enterococcus faecalis; E.c.-Escherichia coli; F.n.-Fusobacterium nucleatum; G(+)—Gram-positive bacteria, } \\
\text { G(-) Gram-negative bacteria, respectively; MRSA—-methicillin-resistant Staphylococcus aureus; P.g.—Porphyromonas } \\
\text { gingivalis; S.a.-Staphylococcus aureus; S.en.-Staphylococcus enterica. Polymers/Nanoparticles/Additivities: AgNPs—silver } \\
\text { nanoparticles; MNPS-metal nanoparticles; PL—-polylactide; PDA-polydopamine. }\end{array}$} \\
\hline
\end{tabular}

Among various inorganic bactericides of medicinal interest, considerable attention has been focused on copper and its salts reflected by over 5000 documents on antibacterial copper and nearly 300 documents on antibacterial metallic copper abstracted by Scopus [34,35], respectively.

In the light of continuous expansion of antibiotic resistance to bacteria, copper nanoparticles (CuNPs) with such attributes of copper as chemical stability $\left(\mathrm{E}_{1}=0.52 \mathrm{~V}\right)$ [36], developed surface and antibacterial prolonged antibacterial activity [37] (a very slow dissolution of metallic copper in water with subsequent formation of very poor soluble copper oxides $\mathrm{Cu}_{2} \mathrm{O} / \mathrm{CuO}$ [37]), as well as a fair abrasion resistance of copper layer's (hardness $230 \mathrm{kgf} \mathrm{mm}^{-2}$ ) [38], contrasted with their negligible contact toxicity toward animals [39-42], became a valuable alternative to traditional antibiotics [25,27,43,44]. The antibacterial activity of copper's metallic surface is regarded as resulting from two supplemental mechanisms-surface-surface interaction of copper and bacteria (contact killing) and/or surface oxidation of copper with subsequent release of antibacterial cupric ions [25,27,43-48].

Polymer-Cu-nanoparticles, being the convenient platform for metallic, antibacterial copper have been formed by a wide array of methods, including chemical, biological synthesis methods, 
and physical methods [49-53], including the magnetic sputtering method [54,55]. This method exhibits an especially convenient character-it is simple and ecofriendly, allowing deposition of the required amount of deposited metal in function of the time applied.

As a part of our experimentation program focused on phosphonic acids [56-59] and textile chemistry of their hybrids with a polymer matrix [60,61], we present the preparation, and characterization of a new multifunctional, biodegradable composite material, PLA-Cu, composite. This composite was obtained by a surface modification of melt-blown poly(lactide) non-wovens with copper, using the direct current (DC) magnetron sputtering method.

\section{Materials and Methods}

\subsection{Materials}

\section{Polymers}

- Poly(lactic) acid, type Ingeo ${ }^{\mathrm{TM}}$ Biopolymer 3251D was purchased from NatureWorks LLC (Minnetonka, MN, USA).

\section{Bacteria subtype}

- Staphylococcus aureus (ATCC 6538);

- Escherchia coli (ATCC 25922).

\section{Fungal subtype}

- Chaetomium globosum (ATCC 6205), bacterial strains and fungal strains from Microbiologics (St. Cloud, MN, USA).

\subsection{Methods}

\subsubsection{Melt-Blown Technique, Fabrication of Poly(lactide) (PLA) Non-Wovens}

Nonwovens samples were manufactured by the melt-blown technique using a laboratory extruder (Axon, Limmared, Sweden) [60]. Samples of nonwoven fabrics were manufactured in the form of a sheet. Processing parameters for fabrication of Poly(lactic) samples are listed in Table 2.

Table 2. Melt-blown technique processing parameters applied for preparation of PLA non-woven.

\begin{tabular}{cc}
\hline \multicolumn{2}{c}{ Processing Parameters } \\
\hline $\begin{array}{c}\text { Polymer yields } \\
\text { Mass per unit area of nonwovens }\end{array}$ & $102 \mathrm{~g} / \mathrm{min}$ \\
Air flow rate & $7-8 \mathrm{~m}^{3} / \mathrm{h}$ \\
Head temperature & \\
Air heater temperature & $260{ }^{\circ} \mathrm{C}$ \\
Temperature of the extruder in zone 3 & $260^{\circ} \mathrm{C}$ \\
Temperature of the extruder in zone 2 & $245^{\circ} \mathrm{C}$ \\
Temperature of the extruder in zone 1 & $195^{\circ} \mathrm{C}$ \\
\hline
\end{tabular}

\subsubsection{Magnetron Sputtering Modification of PLA Non-Wovens}

The obtained poly(lactide) non-wovens were modified using a DC magnetron sputtering system produced by P.P.H. Jolex s. c. (Czestochowa, Poland). The copper target (Testbourne Ltd., Basingstoke, UK) with $99.99 \%$ purity was used. The distance between the target and the substrate was equal to $15 \mathrm{~cm}$. The deposition of coatings was carried out in the atmosphere of argon. In order to optimize the process and avoid the destruction of the PLA substrates, different powers were applied to the target from 350 up to $1000 \mathrm{~W}$. Finally, the following parameters were applied for modification: the power 
discharge of $700 \mathrm{~W}$, with the resulting power density equal to $0.72 \mathrm{~W} / \mathrm{cm}^{2}$ and the working pressure of $2.0 \times 10^{-3}$ mbar. In order to vary the copper content, two different deposition times were applied, i.e., $10 \mathrm{~min}$ (sample name/assignment: PLA-Cu${ }^{0}(10)$ ) and $30 \mathrm{~min}$ (sample name: PLA-Cu${ }^{0}(30)$ ). Sputtered sample size was: $60 \mathrm{~cm} \times 20 \mathrm{~cm}$.

\subsubsection{Scanning Electron Microscopy/Energy-Dispersive Spectroscopy (SEM/EDS)}

The microscopic analysis of fibers was performed on a Tescan Vega 3 scanning electron microscope (Brno, Czech Republic) [60]. Magnification was from 500× to 5000×.

\subsubsection{Attenuated Total Reflection Fourier Transform Infrared Spectroscopy (ATR-FTIR)}

The chemical surface structure of PLA samples was assessed using ATR-FTIR Jasco's 4200 (Tokyo, Japan) spectrometer, with Pike Gladi ATR attachment (Cottonwood, AZ, USA), in the range: $400-4000 \mathrm{~cm}^{-1}$.

2.2.5. Ultraviolet-Visible (UV-VIS) Spectroscopy and Determination of the Protective Properties against UV Radiation

Physical properties as transmittance [\%T] of modified PLA samples were assessed using a Jasco V-550 spectrophotometer (Tokyo, Japan), in the range: $200-800 \mathrm{~nm}$. The same apparatus was used to determine the ultraviolet protection factor (UPF) of samples, according to the standard EN 13758-1:2002 Textiles. Solar UV protective properties. Method of test for apparel fabrics [62], on the basis of Equation (1):

$$
U P F=\frac{\int_{290}^{400} E(\lambda) \varepsilon(\lambda) d(\lambda)}{\int_{290}^{400} E(\lambda) \varepsilon(\lambda) T(\lambda) d(\lambda)}
$$

where:

$\Delta \lambda$ - the wavelength interval of the measurements;

$\varepsilon(\lambda)$ - the erythema action spectrum, measure of the harmfulness of UV radiation for human skin;

$E(\lambda)$ — the solar irradiance;

$T(\lambda)$ - the spectral transmittance at wavelength $\lambda$.

The UPF value of the samples was determined as the arithmetic mean of the UPF values for each of the samples, reduced by the statistical value depending on the number of measurements performed, at a confidence interval of $95 \%$.

\subsubsection{Filtration Properties}

Air permeability of PLA samples was tested according to EN ISO 9237:1998 [63], analogously as samples of PP [59] and/or PLA [60] nonwovens. An FX 3300 Textest AG (Klimatest, Wroclaw, Poland) permeability tester was used.

\subsubsection{Tensile Properties}

Tensile testing of poly(lactic acid) samples was performed according with the EN ISO 10319:2015 standard [64]. Stretching speed was $20 \mathrm{~mm} / \mathrm{min}$. An Tinius Olsen H50KS (Horsham, PA, USA) tester was used.

\subsubsection{Atomic Absorption Spectrometry with Flame Excitation (FAAS)}

Determination of copper content in poly(lactic acid) non-woven fabrics samples was assessed using a single-module Magnum II microwave mineralizer from Ertec (Wroclaw, Poland) and Thermo Scientific Thermo Solar M6 (LabWrench, Midland, ON, Canada) atomic absorption spectrometer equipped with 
a $100 \mathrm{~mm}$ titanium burner, coded lamps with a single-element hollow cathode, background correction: D2 deuterium lamp.

The total copper content of the sample M [mg/kg; ppm] was calculated according to Equation (2) [65]:

$$
M=\frac{C i x V}{m i}\left[\frac{\mathrm{mg}}{\mathrm{kg}}\right]
$$

where:

$C_{\mathrm{i}}-$ metal concentration in the tested solution $[\mathrm{mg} / \mathrm{L}] ;$

$m_{i}$-mass of the mineralized sample [g];

$V$-volume of the sample solution [mL].

\subsubsection{Antibacterial Tests}

The PLA- $\mathrm{Cu}^{0}$ fabrics anti-bacterial activity was tested according to standard: PN-EN ISO 20645:2006 [66], against a colony of Gram-positive bacteria: Staphylococcus aureus (ATCC 6538) and Gram-negative bacteria: Escherchia coli (ATCC 25922) analogously as in PP non-wovens [60]. Antibacterial activity of samples was tested by agar diffusion method using Muller Hinton medium agar $[67,68]$.

\subsubsection{Antifungal Activity}

The antifungal activity of resulting samples was tested according to PN-EN 14119:2005 [69]. The standard indicate tests of antifungal activity on a Chaetomium globosum (ATCC 6205), analogously as in PP nonwovens [60].

\section{Results and Discussion}

\subsection{SEM/EDS}

SEM micrographs of poly(lactide) samples and modified poly(lactide) samples coated with copper $\left(\mathrm{PLA}-\mathrm{Cu}^{0}(\mathrm{t})\right)$ are presented in Figures 1-3, respectively.

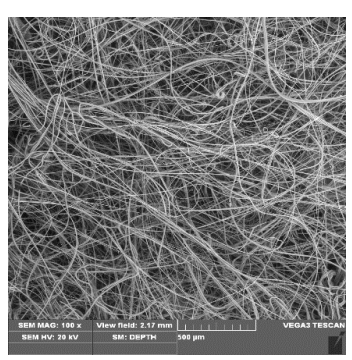

(a)

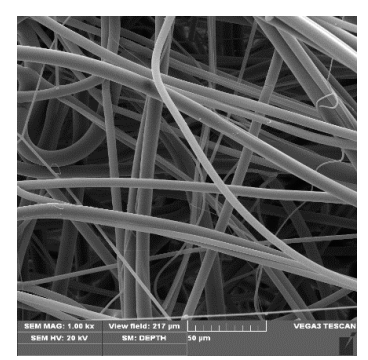

(b)

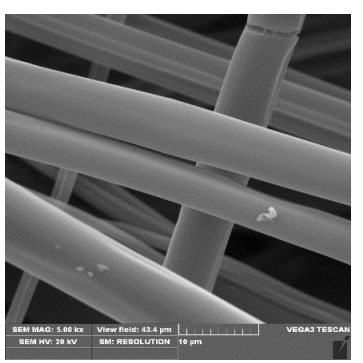

(c)

Figure 1. Scanning electron microscopy (SEM) images of poly(lactide) (PLA) non-woven, magnification: (a) $100 \times$, (b) $1000 \times$, (c) $5000 \times$.

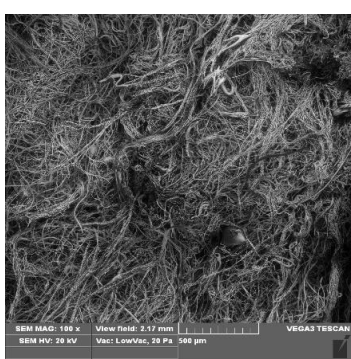

(a)

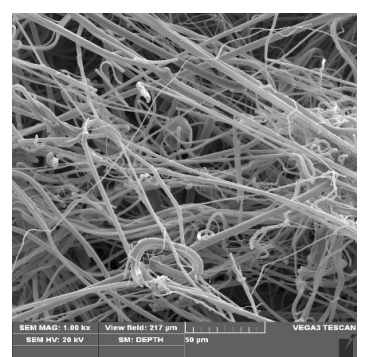

(b)

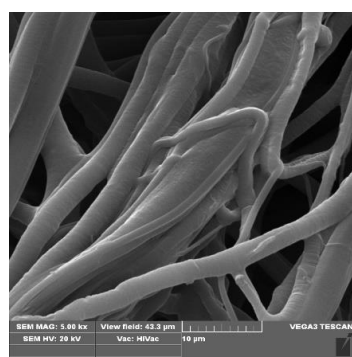

(c)

Figure 2. SEM images of PLA-Cu${ }^{0}(10)$, magnification: (a) $100 \times$, (b) $1000 \times$, (c) $5000 \times$. 


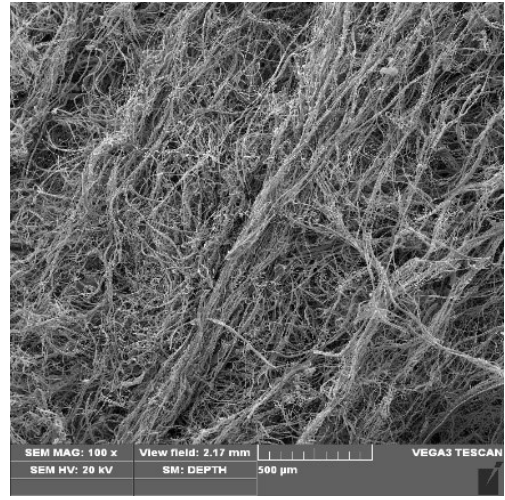

(a)

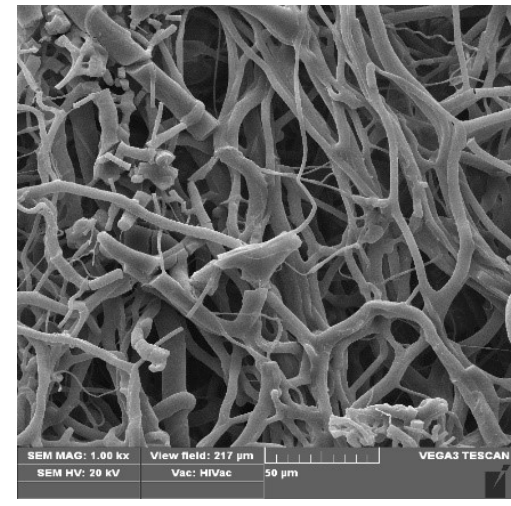

(b)

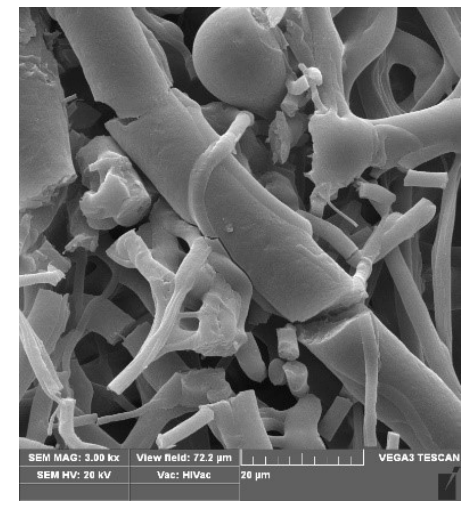

(c)

Figure 3. SEM images of PLA-Cu${ }^{0}(30)$, magnification: (a) $100 \times$, (b) $1000 \times$, (c) $3000 \times$.

The SEM images of the starting PLA non-woven and PLA-Cu ${ }^{0}(t)$ composites reflect the changes in their morphology occurring during sputtering process (PLA $\rightarrow \mathrm{PLA}-\mathrm{Cu}^{0}(10) \rightarrow \mathrm{PLA}-\mathrm{Cu}^{0}(30)$ ). Thus, PLA fibres images present uniform randomly oriented fibers, with interconnected pores and space with relatively smooth surface in PLA fibre images (Figure 1). The diameters of poly(lactide) fibers applied ranged: $0.65-5.0 \mu \mathrm{m}$ (Figure 1c).

PLA- $\mathrm{Cu}^{0}(10)$ composites images (Figure 2) show uniform randomly oriented fibers (Figure $2 \mathrm{~b}, \mathrm{c}$ ) and visible layer of copper on the surface fibers (Figure 2c). On the other hand, PLA-Cu ${ }^{0}(30)$ composite images also present uniform randomly oriented fibers (Figure 3a), but with high fibers crack content (Figure 3b,c). the PLA-Cu0(30) sample shows a substantial contribution (20-30\%) of shorter fragments (length: 10 to $30 \mu \mathrm{m}$; diameter: 2 to $13 \mu \mathrm{m}$ ), without sharp edges, $\mathrm{Cu}$ covered. Fiber fracture and damage of the PLA-Cu${ }^{0}(30)$ composite during copper sputtering of PLA in $30 \mathrm{~min}$. period suggests application of shorter process times, for example up to $10 \mathrm{~min}$.

EDS analysis results obtained for PLA and PLA-Cu ${ }^{0}(t)(t=10 \mathrm{~min}$ and $30 \mathrm{~min})$ are presented in Table 3.

Table 3. Energy-dispersive spectroscopy (EDS) analysis results of PLA and PLA-Cu ${ }^{0}(\mathrm{t})$.

\begin{tabular}{|c|c|c|c|c|c|c|c|c|c|c|c|}
\hline \multirow[b]{3}{*}{ Atom } & \multirow{2}{*}{\multicolumn{3}{|c|}{ PLA (Calc.) }} & \multicolumn{8}{|c|}{ EDS Determinations } \\
\hline & & & & \multicolumn{2}{|c|}{ PLA } & \multicolumn{3}{|c|}{ PLA-Cu ${ }^{0}(10)^{/ a}$} & \multicolumn{3}{|c|}{ PLA-Cu${ }^{0}(30)^{/ a}$} \\
\hline & C & $\mathrm{H}$ & $\mathrm{O}$ & $\mathrm{C}$ & $\mathrm{O}$ & C & $\mathrm{O}$ & $\mathrm{Cu}$ & C & $\mathrm{O}$ & $\mathrm{Cu}$ \\
\hline$\% / b$ & 50.0 & 5.6 & 44.4 & 51.7 & 48.33 & 42.33 & 38.13 & 19.55 & 21.00 & 12.14 & 66.86 \\
\hline Std. dev./c & & & & 0.11 & 0.11 & 0.04 & 0.09 & 0.13 & 0.16 & 0.30 & 0.43 \\
\hline $\mathrm{C}: \mathrm{O}: \mathrm{Cu} /{ }^{\mathrm{d}}[\% / \%]$ & \multicolumn{3}{|c|}{ 1:0.88:0 } & & $3: 0$ & \multicolumn{3}{|c|}{ 1:0.90:0.46 } & \multicolumn{3}{|c|}{ 1:0.58:3.18 } \\
\hline $\mathrm{Ml}^{\mathrm{e}}$ & 4.17 & 5.6 & 2.76 & 4.31 & 3.02 & 3.53 & 2.38 & 0.31 & 1.75 & 0.74 & 1.05 \\
\hline $\mathrm{SMF}^{/ \mathrm{f}}$ & \multicolumn{3}{|c|}{$\mathrm{CH}_{1.3} \mathrm{O}_{0.66} ; \mathrm{C}_{3} \mathrm{H}_{3.9} \mathrm{O}_{1.98}$} & \multicolumn{2}{|c|}{$\mathrm{C}_{3} \mathrm{O}_{2.1}$} & \multicolumn{3}{|c|}{$\mathrm{CO}_{0.67} \mathrm{Cu}_{0.09} ; \mathrm{C}_{3} \mathrm{O}_{2} \mathrm{Cu}_{0 \cdot 27}$} & \multicolumn{3}{|c|}{$\mathrm{CO}_{0.4} \mathrm{Cu}_{0.6} ; \mathrm{C}_{3} \mathrm{O}_{1.2} \mathrm{Cu}_{1.8}$} \\
\hline
\end{tabular}

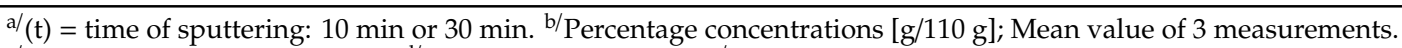

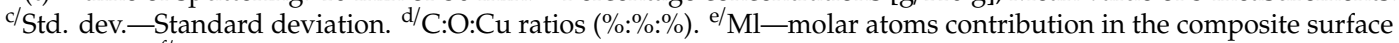

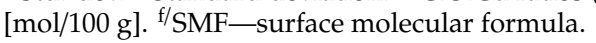

The content of carbon and oxygen components of poly(lactic acid) (PLA) (without of hydrogen) is similar to atomic "bulk" analysis of PLA $(C=50.0$ and $\mathrm{O}=44.4 \%)$. The surface modification of poly(lactic acid) samples using surface copper sputtering leads to appearance of copper, which contents rapidly increases during prolongation of sputtering $\left(19.55 \%\right.$ for PLA-Cu${ }^{0}(10)$, and 66.86 for PLA-Cu $\left.{ }^{0}(30)\right)$ and

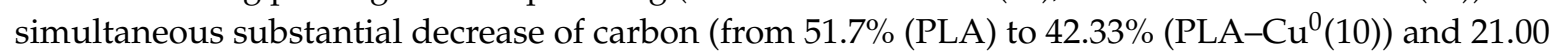

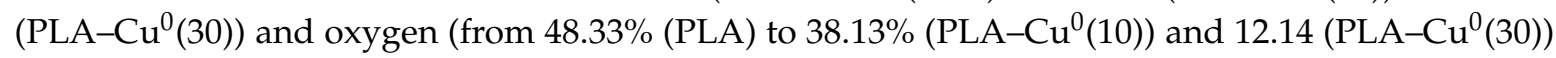
contents, respectively. This causes a subsequent change of the "surface molecular formula" (SMF) from $\mathrm{C}_{3} \mathrm{O}_{2}$ for PLA, to $\mathrm{C}_{3} \mathrm{O}_{2} \mathrm{Cu}_{0.27}$ for PLA-Cu ${ }^{0}(10)$ and/or to $\mathrm{C}_{3} \mathrm{O}_{1 \cdot 2} \mathrm{Cu}_{1.8}$ for PLA- $\mathrm{Cu}^{0}(30)$. These results suggest preferential deposition of copper atoms on the oxygens of carboxylate fragments of the lactide unit $(-\mathrm{C}(=\mathrm{O})-\mathrm{O}-)$, as spatially more available due to flat structures of the carboxylic ester function. 


\subsection{ATR-FTIR Spectra}

The recorded ATR-FTIR spectra for PLA and PLA-Cu ${ }^{0}(t)(t=10 \mathrm{~min}, 30 \mathrm{~min})$ composites are presented in Figure 4. Characteristic FTIR signals of the starting PLA and derived PLA-Cu(t) composites are summarized in Table 4.

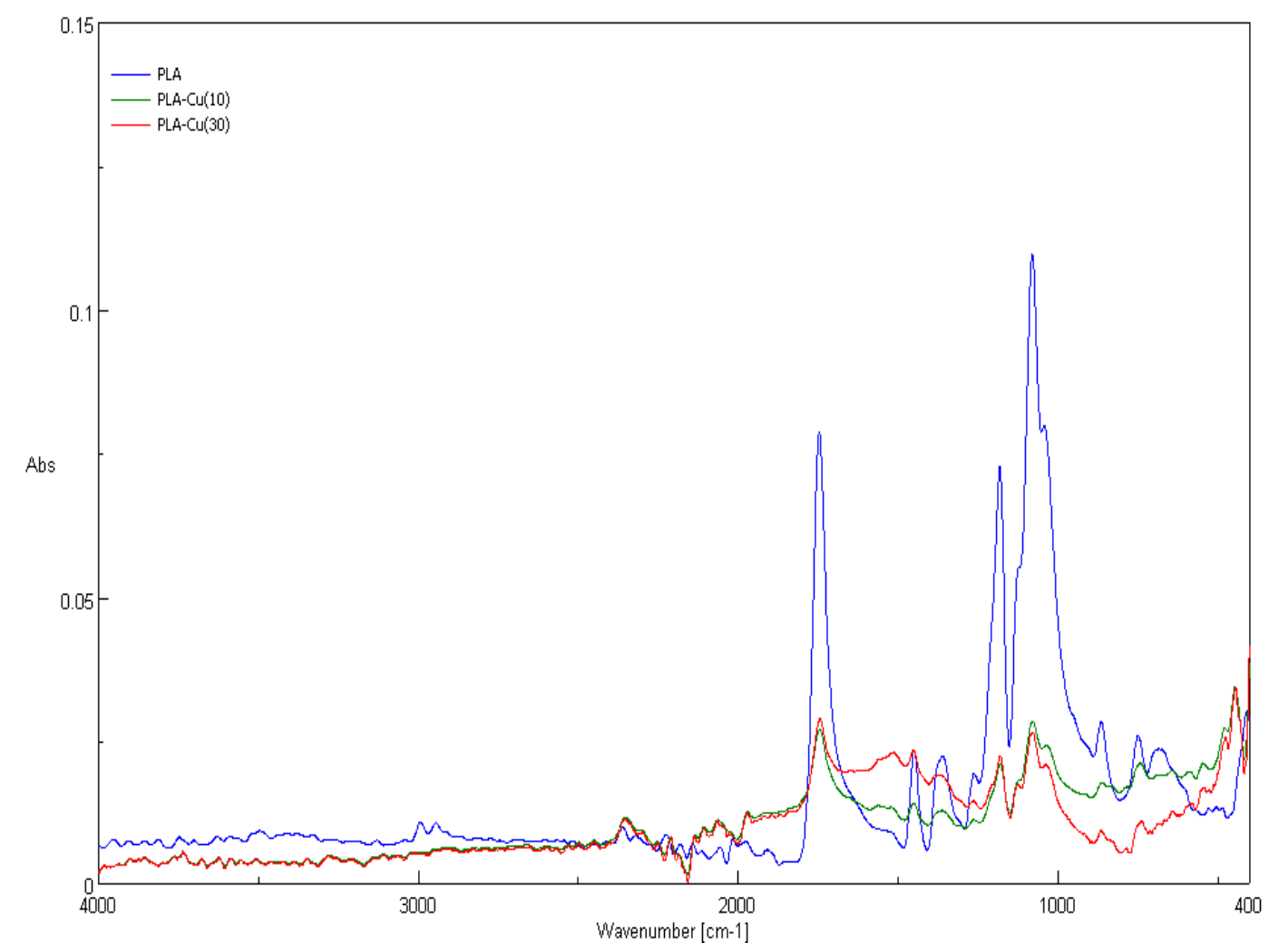

Figure 4. Attenuated total reflection Fourier transform infrared spectroscopy (ATR-FTIR) spectra of poly(lactic acid) non-woven and PLA-Cu${ }^{0}(10)$ and $\mathrm{PLA}-\mathrm{Cu}^{0}(30)$ composite.

Table 4. Characteristic FTIR bands determined for PLA non-woven and PLA-Cu${ }^{0}(10)$ composite.

\begin{tabular}{|c|c|c|c|c|c|c|}
\hline \multirow{2}{*}{\multicolumn{3}{|c|}{ PLA }} & \multicolumn{4}{|c|}{$\operatorname{PLA}-\mathrm{Cu}^{0}(\mathrm{t})$} \\
\hline & & & \multicolumn{2}{|c|}{ PLA-Cu $\mathbf{u}^{0}(10)$} & \multicolumn{2}{|c|}{ PLA-Cu${ }^{0}(30)$} \\
\hline IR $\left[v / \mathrm{cm}^{-1}\right]$ & Intensity $^{/ a}$ & Assignment [70] & $\operatorname{IR}\left[v / \mathrm{cm}^{-1}\right]$ & Intensity $^{/ \mathbf{a}}$ & $\operatorname{IR}\left[v / \mathrm{cm}^{-1}\right]$ & Intensity \\
\hline 2997 & 0.01 & $v_{\text {as }} \mathrm{CH}_{3}$ & - & - & - & - \\
\hline 2947 & 0.01 & $v_{\mathrm{s}} \mathrm{CH}_{3}$ & - & - & 2947 & - \\
\hline 1760 & 0.08 & $v \mathrm{C}=\mathrm{O}$ & 1760 & 0.03 & 1760 & 0.03 \\
\hline 1620 & 0.013 & & 1620 & 0.014 & 1620 & 0.02 \\
\hline 1452 & 0.02 & $\delta_{\text {as }} \mathrm{CH}_{3}$ & 1452 & 0.01 & 1452 & 0.02 \\
\hline 1388-1368 & 0.02 & $\delta_{\mathrm{s}} \mathrm{CH}_{3}$ & 1348-1388 & 0.01 & 1348-1388 & 0.02 \\
\hline 1368-1360 & 0.02 & $\delta_{1} \mathrm{CH}+\delta_{\mathrm{s}} \mathrm{CH}_{3}$ & 1368-1360 & 0.01 & 1368-1360 & - \\
\hline 1270 & 0.02 & $\delta \mathrm{CH}+v \mathrm{COC}$ & 1270 & 0.01 & 1270 & 0.01 \\
\hline $1215-1185$ & 0.07 & $v_{\mathrm{as}} \mathrm{COC}+\mathrm{r}_{\mathrm{as}} \mathrm{CH}_{3}$ & 1215-1185 & 0.02 & $1215-1185$ & 0.02 \\
\hline 1130 & 0.05 & $\mathrm{r}_{\mathrm{as}} \mathrm{CH}_{3}$ & 1130 & 0.02 & 1130 & 0.02 \\
\hline 1100-1090 & 0.11 & $v_{\mathrm{s}} \mathrm{COC}$ & 1100-1090 & 0.03 & 1100-1090 & 0.03 \\
\hline 1045 & 0.08 & $v \mathrm{C}-\mathrm{CH}_{3}$ & 1045 & 0.02 & 1045 & 0.02 \\
\hline $875-860$ & 0.03 & $v \mathrm{C}-\mathrm{COO}$ & $875-860$ & 0.02 & $875-860$ & 0.01 \\
\hline $760-740$ & 0.03 & $\delta \mathrm{C}=\mathrm{O}$ & $760-740$ & 0.02 & $760-740$ & 0.01 \\
\hline $715-695$ & 0.02 & $\gamma \mathrm{C}=\mathrm{O}$ & $715-695$ & - & $715-695$ & - \\
\hline
\end{tabular}

Legend: Band assignment ${ }^{\prime a}$ : as—asymmetric; $\delta$-deformation; $r$-rocking; s—symmetric; sh—shoulder; $\gamma$-out-of-plane bending mode; $v \longrightarrow$ stretching vibration. Band intensity ${ }^{b}$ : Abs. were approximated to a second decimal place. 
The ATR-FTIR spectra of PLA as well as PLA- $\mathrm{Cu}^{0}(\mathrm{t})$ composites are similar in a shape, exhibiting absorbance up to 0.12 . Generally the major band intensities of PLA are much stronger than corresponding bands of PLA- $\mathrm{Cu}^{0}(\mathrm{t})$ composites, which are almost identical.

The strongest bands of the presented spectra are: $1760\left(0.09\right.$ (PLA) and 0.03 (PLA-Cu $\left.{ }^{0}(10)\right)$ identified as $v \mathrm{C}=\mathrm{O} ; 1270\left(0.07\right.$ (PLA) and 0.01 (PLA-Cu $\left.{ }^{0}(10)\right)$-identified as $\delta \mathrm{CH}+v C O C ; 1215-1185(0.08$ (PLA) and 0.03 (PLA-Cu ${ }^{0}(10)$ ) -identified as $v_{\mathrm{as}} \mathrm{COC}+\mathrm{r}_{\mathrm{as}} \mathrm{CH}_{3} ; 1130\left(0.12\right.$ (PLA) and 0.03 ( $\mathrm{PLA}-\mathrm{Cu}^{0}(10)$ ) -identified as $\mathrm{r}_{\mathrm{as}} \mathrm{CH}_{3} ; 1100-1090$ (0.06 (PLA) and 0.13 (PLA-Cu ${ }^{0}(10)$ ) -identified as $v_{\mathrm{s}}$ COC, and 1045 (0.08 (PLA) and $0.02\left(\mathrm{PLA}-\mathrm{Cu}^{0}(10)\right)$ identified as $\vee \mathrm{C}-\mathrm{CH}_{3}$.

The bands observed in the low-frequency region $740-695 \mathrm{~cm}^{-1}$ can be assigned to: $\delta \mathrm{C}=\mathrm{O}\left(760-740 \mathrm{~cm}^{-1}\right.$, absorbances 0.03 (PLA) and $0.02\left(\mathrm{PLA}-\mathrm{Cu}^{0}(10)\right)$ and $\gamma \mathrm{C}=\mathrm{O}\left(715-695 \mathrm{~cm}^{-1}\right.$, absorbances 0.02 (PLA) and $0.01\left(\right.$ PLA-Cu$\left.^{0}(10)\right)$.

The spectra of PLA-Cu${ }^{0}(t)$ offered noticeable differences, mainly at wavelength $1620 \mathrm{~cm}^{-1}$ (absorbances 0.00 (PLA), 0.013 (PLA-Cu ${ }^{0}(10)$ and 0.021 (PLA-Cu ${ }^{0}(30)$ ). Also at $500-400 \mathrm{~cm}^{-1}$ absorbances derived from $\mathrm{PLA}-\mathrm{Cu}^{0}(\mathrm{t})$ composites are higher than for starting PLA. These differences can presumably have resulted from copper's presence in the PLA and are similar to those obtained by Diaz-Visurraga et al. in a FTIR study of alginate-stabilized copper nanoparticles [71].

\subsection{UV-VIS Spectrometry and Determination of the Protective Properties against UV Radiation}

Transmittance spectra [\%T] of PLA samples and PLA-Cu${ }^{0}(t)$ hybrids $\left(\operatorname{PLA}-\mathrm{Cu}^{0}(10)\right.$ or PLA-Cu$\left.{ }^{0}(30)\right)$, recorded in the ranges $\lambda=200-800 \mathrm{~nm}$ is presented in Figure 5 .

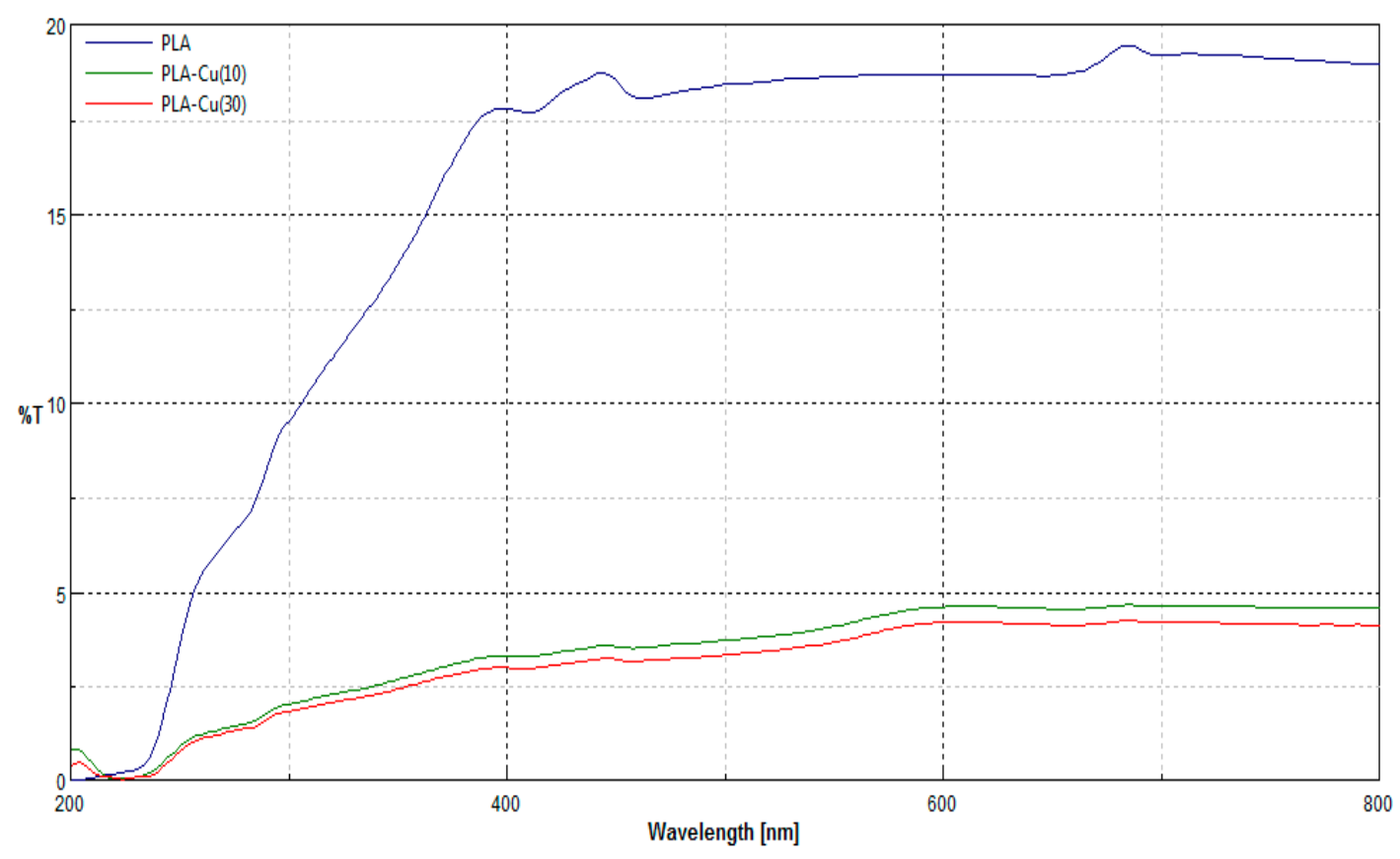

Figure 5. Transmittance spectra of PLA and PLA- $\mathrm{Cu}^{0}(\mathrm{t})$ hybrids $\left(\mathrm{PLA}-\mathrm{Cu}^{0}(10)\right.$ and $\left.\mathrm{PLA}-\mathrm{Cu}^{0}(30)\right)$.

The transmittance (\%T) spectra in the range $\lambda=200-800 \mathrm{~nm}$ of the modified PLA non-woven by magnetron sputtering show that the samples after modification reveal changes in the macrostructure expressed by a decrease in transmittance, the reduction in transmission is caused by an additional layer of copper on the surface of the samples. The transmittance spectra of modified samples (PLA-Cu ${ }^{0}(10)$, PLA- $\left.\mathrm{Cu}^{0}(30)\right)$ had similar spectral characteristics and quite a similar level of transmittance in the entire spectral range when compared to control samples (without modification).

Table 5 compare average transmittance $(\mathrm{T} \%)$ and calculated UPF values of modified samples $\left(\mathrm{PLA}-\mathrm{Cu}^{0}(10), \mathrm{PLA}-\mathrm{Cu}^{0}(30)\right)$ with those non-modified. The transmittance $(\% \mathrm{~T})$ spectra in the range $\lambda=290-400 \mathrm{~nm}$ are presented in Figure 5. 
Table 5. Ultraviolet protection factor (UPF) values of non-woven fabric samples modified by magnetron sputtering.

\begin{tabular}{cccc}
\hline Parameter & PLA & PLA-Cu$^{\mathbf{0}} \mathbf{( 1 0 )}$ & PLA-Cu$^{\mathbf{0}} \mathbf{( 3 0 )}$ \\
\hline UPF & 9.36 & 44.83 & 49.32 \\
average $\% \mathrm{~T}, \lambda=290-400 \mathrm{~nm}$ & 13.5 & 2.66 & 2.42 \\
\hline
\end{tabular}

The results have been measured in triplicate and presented as a mean value wit \pm deviation approximately $2 \%$.

Samples modified with copper obtain a UPF value $>40$, calculated on the basis of transmittance measurements for $\lambda=290-400 \mathrm{~nm}$ (according to Formula (1)). This result indicates that the modification performed imparts proper barrier properties against UV radiation according to PN-EN 13758-1:2002 [62].

\subsection{Technical Parameters}

Technical parameters of new composite materials were focused on tensile strength and filtration properties. Filtration properties expressed by the air permeability and were tested for starting poly(lactic acid) nonwoven and $\mathrm{PLA}-\mathrm{Cu}^{0}(\mathrm{t})$ composites. Results of filtration parameters are showed in Table 6. The results of tensile strength properties: relative elongation at maximum load [\%] and durability for stretching $[\mathrm{kN} / \mathrm{m}]$ of initial PLA samples and PLA-Cu ${ }^{0}(\mathrm{t})$ composites are listed in Table 7 .

Table 6. The air flow resistance of PLA and modified PLA-Cu ${ }^{0}(t)$ sample according to: EN ISO 9237:1998 [63].

\begin{tabular}{ccccc}
\hline Parameter & & PLA & PLA-Cu$^{\mathbf{0}} \mathbf{( 1 0 )}$ & PLA-Cu$^{\mathbf{0}} \mathbf{( 3 0 )}$ \\
\hline Average air permeability $^{\mathrm{a}, \mathrm{b} /[\mathrm{mm} / \mathrm{s}],}$ & $50 \mathrm{~Pa}$ & 458 & 437 & 388 \\
pressure decrease: & $100 \mathrm{~Pa}$ & 853 & 839 & 778 \\
\hline
\end{tabular}

a/ The results have been measured in triplicate and presented as a mean value with deviation approximately $\pm 2 \%$.

$\mathrm{b} /$ The results were approximated to full numbers.

Table 7. Results of tensile strength test of PLA and hybrids PLA- $\mathrm{Cu}^{0}(\mathrm{t})$, according to: EN ISO 10319:2015-08 [64].

\begin{tabular}{cccc}
\hline Parameter & PLA & PLA-Cu$^{\mathbf{0}} \mathbf{( 1 0 )}$ & PLA-Cu $^{\mathbf{0}} \mathbf{( 3 0 )}$ \\
\hline Tensile strength $[\mathrm{kN} / \mathrm{m}]^{\mathrm{a}, \mathrm{b} /}$ & 0.05 & 0.58 & 0.070 \\
Relative elongationat maximum load $[\%]^{\mathrm{a}, \mathrm{b} /}$ & 11.98 & 28.75 & 2.65 \\
\hline
\end{tabular}

$\mathrm{a} /$ The results have been measured in triplicate and presented as a mean values with deviation approximately $\pm 2 \%$.

b/Values were approximated to a second decimal place.

The results of air flow resistance of modified polylactide show that 10 min magnetron sputtering modifications slightly decrease filtration parameters of PLA sample: PLA vs. PLA-Cu ${ }^{0}(10): 458$ vs. 437 at $50 \mathrm{~Pa}$ and 853 vs. $839100 \mathrm{~Pa}$, respectively but $30 \mathrm{~min}$ magnetron sputtering reduces filtration parameters: PLA vs. PLA-Cu${ }^{0}(30): 458$ vs. 388 at $50 \mathrm{~Pa}$ and 853 vs. 778 at $100 \mathrm{~Pa}$, respectively.

The listed tensile strength results of PLA and PLA- $\mathrm{Cu}^{0}(\mathrm{t})$ composites show the ca. 11-fold increase for PLA-Cu ${ }^{0}(10)\left(0.575[\mathrm{kN} / \mathrm{m})\right.$ and 1.21-fold increase for PLA-Cu ${ }^{0}(30)(0.071[\mathrm{kN} / \mathrm{m}])$, compared with unmodified PLA non-woven $(0.05[\mathrm{kN} / \mathrm{m}]$.

The results of relative elongation at maximum load [\%] of poly(lactic acid) non-woven and PLA-Cu $\mathrm{u}^{0}(\mathrm{t})$ composites show ca. 2.5-fold increase of this parameter of PLA-Cu $\mathrm{u}^{0}(10)$ compared with PLA (PLA vs. PLA-Cu ${ }^{0}(10): 11.98 \%$ vs. $28.75 \%$ ) and ca. 4.5 -fold decrease for PLA-Cu ${ }^{0}(30)$ compared with PLA (PLA vs. PLA-Cu ${ }^{0}(30): 11.98 \%$ vs. $2.65 \%$ ). These results indicate that the sample PLA- $\mathrm{Cu}^{0}(10)$ has a more beneficial flexibility and stronger structure compared with PLA. It is obvious also that very high loading of $\mathrm{Cu}$ on the PLA surface in PLA-Cu${ }^{0}(30)$ influenced negatively on the mechanical properties of this composite. 


\subsection{Flame Atomic Absorption Spectrometry}

Determination of copper content in PLA-Cu $\mathrm{u}^{0}(\mathrm{t})$ composites was assessed by the Flame Atomic Absorption Spectrometry (FAAS) method [65] and listed in Table 8.

Table 8. Results of determination of copper content in PLA composite samples.

\begin{tabular}{cccc}
\hline \multirow{2}{*}{ Composite } & $\begin{array}{c}\text { Magnetron Sputtering Deposition } \\
\text { Times of Copper [min.] }\end{array}$ & \multicolumn{2}{c}{$\mathrm{Cu}$ Concentration } \\
\cline { 3 - 4 } & - & 0.004 & \\
& 10 & $\mathbf{k g}]$ & {$[\mathbf{m o l} / \mathbf{k g}]$} \\
\hline PLA & 30 & 9.91 & 0.16 \\
PLA-Cu $-\mathrm{Cu}^{0}(30)$ & $30)$ & 27.89 & 0.43 \\
\hline
\end{tabular}

The results have been measured in triplicate and presented as a mean value with \pm deviation approximately $2 \%$.

The results determination of copper content in poly(lactic acid) composite show that copper content in poly(lactic acid) composite samples depends on the applied magnetron sputtering deposition times (PLA-Cu ${ }^{0}(10): 10 \mathrm{~min}-9.91 \mathrm{~g} / \mathrm{kg}$; PLA-Cu${ }^{0}(30): 30 \mathrm{~min}-27.89 \mathrm{~g} / \mathrm{kg}$ ) and the magnetron sputtering of copper deposition process is almost linear. The copper content in poly(lactic acid) composite indicate also that magnetron sputtering process is quite precise and distribution of copper in a composites bulk is uniform.

\subsection{Antimicrobial Properties}

Antibacterial Activity

The polylactide nonwoven (PLA) and polylactide-copper composites PLA-Cu ${ }^{0}(\mathrm{t})$ were subjected to antimicrobial activity tests against Gram-negative Escherichia coli (ATCC11229) and Gram-positive Staphylococcus aureus (ATCC 6538) (Table 9).

Table 9. Results of tests on the antibacterial activity of polylactide nonwoven (PLA) and polylactide-copper composites $\left(\mathrm{PLA}-\mathrm{Cu}^{0}(10)\right.$ and PLA-Cu$\left.{ }^{0}(30)\right)$ on the basis of standards EN-ISO 20645:2006 [66].

\begin{tabular}{ccc}
\hline \multirow{2}{*}{ Sample Name } & \multicolumn{2}{c}{ Bacterial Average Inhibition Zone(mm) } \\
\cline { 2 - 3 } & Escherichia coli & Staphylococcus aureus \\
\hline PLA & 0 & 0 \\
PLA-Cu ${ }^{0}(10)$ & 2 & 1 \\
PLA-Cu $(30)$ & 2 & 1 \\
\hline
\end{tabular}

Concentration of inoculum amount of live bacteria (bacterial suspension): E. coli: colony-forming units $(\mathrm{CFU}) / \mathrm{mL}=1.2 \times 10^{8}$, S. aureus: $\mathrm{CFU} / \mathrm{mL}=1.7 \times 10^{8}$.

Results of antimicrobial studies demonstrate antimicrobial protection against different bacterial species of new composites for Escherichia coli and Staphylococcus aureus (Table 8) according to standard: PN-EN ISO 20645:2006 [66]. Antimicrobial properties of composite samples expressed by strong visible inhibition zones of bacterial growth on inoculated agar Petri dishes (Figure 6) and no visible bacteria under the modified samples. Any antibacterial effect was observed for the unmodified sample (PLA). It is worth noting that 0.03 molar solutions of $\mathrm{CuSO}_{4}(2 \mathrm{mg} / \mathrm{mL}$ ) are not bactericidal (Growth Inhibition Zone $=0$ ) for several gram positive bacteria (e.g., S. aureus), gram negative bacteria (e.g., E. coli) bacteria as well as fungi species (e.g., Candida family) [72]. 

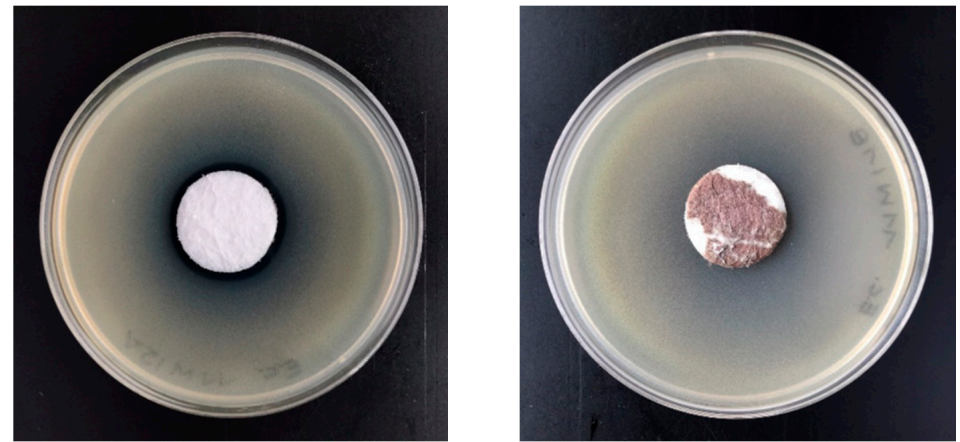

(a)
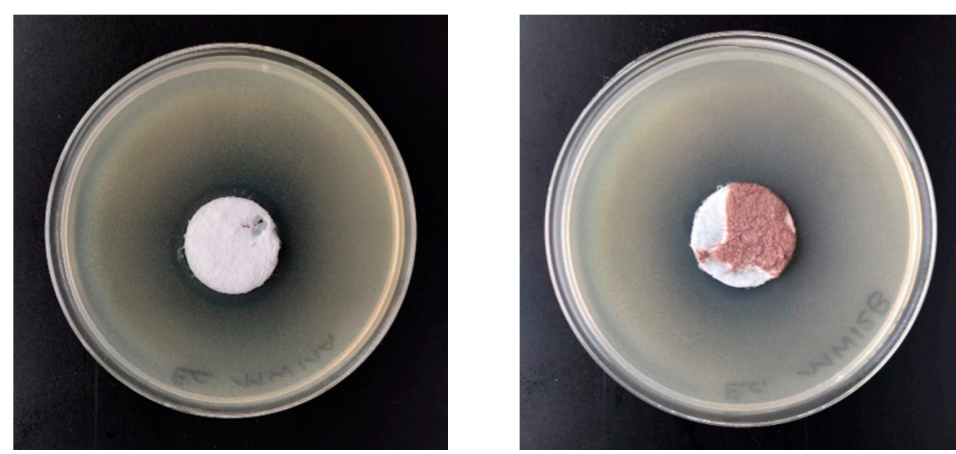

(b)

Figure 6. Inhibition zones of bacterial growth on Petri dishes, $\mathrm{PLA}-\mathrm{Cu}^{0}(10)$ sample: Escherichia Coli (a);

Staphylococcus aureus (b).

\subsection{Antifungal Activity}

Results of antifungal tests against a Chaetomium globosum (ATCC 6205) of poly(lactide) nonwoven (PLA) and poly(lactide)-copper composites PLA- $\mathrm{Cu}^{0}(\mathrm{t})$ are listed in Table 10 and Figure 7.

Table 10. Results of antifungal activity tests of PLA composites on the basis of standard EN 14119: 2005 [69].

\begin{tabular}{ccc}
\hline Sample Name & \multicolumn{2}{c}{ Fungal Average Inhibition Zone (mm) } \\
\hline PLA & 0 & Visible growth on sample surface \\
PLA-Cu $\mathrm{Cu}^{0}(10)$ & 1 & No visible growth on sample surface \\
PLA-Cu $(30)$ & 3 & \\
\hline
\end{tabular}

Inoculum concentration (determined using a Thoma chamber), number of fungal spores in $1 \mathrm{~mL}[\mathrm{CFU} / \mathrm{mL}]=2.2 \times 10^{6}$.

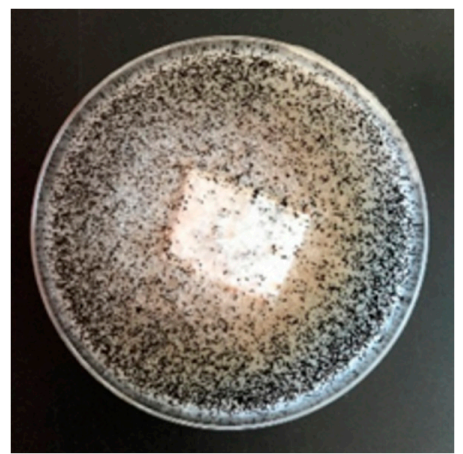

(a)

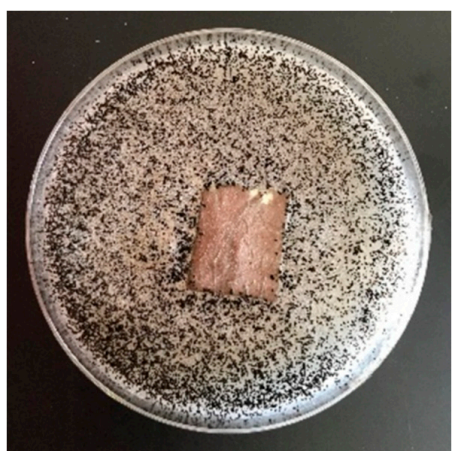

(b)

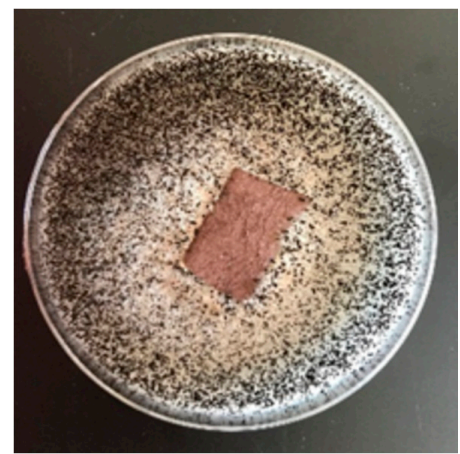

(c)

Figure 7. The sample antimicrobial activity tests against Chaetomium globosum. Inhibition properties of fungal growth on Petri dishes: (a)-PLA, (b)-PLA-Cu${ }^{0}(10)$; (c) $-\mathrm{PLA}-\mathrm{Cu}^{0}(30)$. 
Modification of non-woven fabrics provide antifungal properties for Chaetomium globosum, expressed by no visible growth under the microscope (50× magnification). PLA non-woven fabrics without magnetron sputtering modification exhibit strong growth covering the surface of the control sample (Table 10, Figure 7).

\section{Conclusions}

The major contribution of this study was offering a new method for obtaining a multi-functional composite materials. The fabrication of new composite materials was performed by magnetron sputtering deposition of copper on the melt-blown poly(lactide) non-woven fabrics. The structure and mechanical properties of the obtained new composite products were characterized by FTIR spectrometry, UV/VIS transmittance, scanning electron microscopy (SEM), atomic absorption spectrometry with flame excitation (FAAS), tensile strength test and air permeability. The polylactide-copper composites were subjected to antimicrobial activity tests against: Escherichia coli, Staphylococcus aureus, Chaetomium globosum. The most important features of the new composite materials PLA- $\mathrm{Cu}^{0}$ are:

- eco-friendly, full biodegradable composite product;

- fabricated by clean and zero-waste process;

- improvement of technical parameters, including a tensile strength, air permeability and barrier properties against $\mathrm{UV}$ radiation of $\mathrm{PLA}-\mathrm{Cu}^{0}$ synthesized in comparison with starting raw PLA non-woven fabrics;

- composite with potential antimicrobial properties.

The listed attributes of the PLA-Cu $\mathrm{Cu}^{0}$ synthesized composites should find application in biomedical areas, and also as a microbiostatic material. Additionally, in the period when clinical waste are a major environmental burden, increasing interests should be paid to new biodegradable composite products fabricated by a clean process.

Author Contributions: M.H.K. developed the concept and designed experiments, performed experiments, analyzed data and wrote the paper; Z.M. performed experiments, analyzed the data and participated in the publication preparation; A.K. performed experiments, analyzed the data and participated in the publication preparation; A.L.-K. performed experiments. All authors have read and agree to the published version of the manuscript.

Funding: This research was funded by the Polish Ministry of Science and Higher Education within statutory research work carried out at the The Lukasiewicz Research Network-Textile Research Institute, Lodz, Poland.

Acknowledgments: This work was partly supported by National Science Centre, Poland via Grant: Miniatura 2, No. 2018/02/X/ST8/01775.

Conflicts of Interest: The authors declare no conflict of interest.

\section{References}

1. Garlotta, D. A literature review of poly(lactic acid). J. Polym. Environ. 2001, 9, 63-84. [CrossRef]

2. Auras, R.; Lim, L.T.; Selke, S.E.M.; Tsuji, H. Poly(Lactic Acid): Synthesis, Structures, Properties, Processing, and Applications; John Wiley \& Sons, Inc.: Hoboken, NJ, USA, 2010.

3. Zhou, J.; Han, S.; Dou, Y.; Lu, J.; Wang, C.; He, H.; Li, X.; Zhang, J. Nanostructured poly(l-lactide) matrix as novel platform for drug delivery. Int. J. Pharm. 2013, 448, 175-188. [CrossRef] [PubMed]

4. Pandey, A.K.; Dwivedi, A.K. Recent advancement in wound healing dressing material. Int. J. Pharm. Sci. Res. 2019, 10, 2572-2577. [CrossRef]

5. Sharif, A.; Mondal, S.; Hoque, M.E. Polylactic acid (PLA)-based nanocomposites: Processing and properties. In Bio-Based Polymers and Nanocomposites: Preparation, Processing, Properties \& Performance; Springer Nature: Cham, Switzerland, 2019; pp. 233-254.

6. Alam, F.; Shukla, V.R.; Varadarajan, K.M.; Kumar, S. Microarchitected 3D printed polylactic acid (PLA) nanocomposite scaffolds for biomedical applications. J. Mech. Behav. Biomed. Mater. 2020, 103, 103576. [CrossRef] [PubMed] 
7. Essa, D.; Kondiah, P.P.D.; Choonara, Y.E.; Pillay, V. The Design of poly(lactide-co-glycolide) nanocarriers for medical applications. Front. Bioeng. Biotechnol. 2020, 8, 48. [CrossRef] [PubMed]

8. Wu, D.; Spanou, A.; Diez-Escudero, A.; Persson, C. 3D-printed PLA/HA composite structures as synthetic trabecular bone: A feasibility study using fused deposition modeling. J. Mech. Behav. Biomed. Mater. 2020, 103, 103608. [CrossRef]

9. Schkarpetkin, D.; Reise, M.; Wyrwa, R.; Völpel, A.; Berg, A.; Schweder, M.; Schnabelrauch, M.; Watts, D.C.; Sigusch, B.W. Development of novel electrospun dual-drug fiber mats loaded with a combination of ampicillin and metronidazole. Dent. Mater. 2016, 32, 951-960. [CrossRef]

10. Luo, D.; Zhang, X.; Shahid, S.; Cattel, M.J.; Gould, D.J.; Sukhorukov, G.B. Electrospun poly(lactic acid) fibers containing novel chlorhexidine particles with sustained antibacterial activity. Biomater. Sci. 2016, 5, 111-119. [CrossRef]

11. Olmo, C.; Franco, L.; del Valle, L.J.; Puiggalí, J. Preparation of medicated polylactide micropieces by means of ultrasonic technology. Appl. Sci. 2019, 9, 2360. [CrossRef]

12. Parwe, S.P.; Chaudhari, P.N.; Mohite, K.K.; Selukar, B.S.; Nande, S.S.; Garnaik, B. Synthesis of ciprofloxacin-conjugated poly (L-lactic acid) polymer for nanofiber fabrication and antibacterial evaluation. Int. J. Nanomed. 2014, 9, 1463-1477. [CrossRef]

13. Li, B.; He, C.; Jiang, X.; Yarmolenko, M.A.; Piliptsou, D.G.; Rogachev, A.A.; Rogachev, A.V.; Du, B. Structures and antibacterial properties of pla-based ciprofloxacin composite films deposited by low-electron beam dispersion. Eurasian Chem. Technol. J. 2020, 22, 35-42. [CrossRef]

14. Cui, S.; Sun, X.; Li, K.; Gou, D.; Zhou, Y.; Hu, J.; Liu, Y. Polylactide nanofibers delivering doxycycline for chronic wound treatment. Mat. Sci. Eng. C 2019, 104, 109745. [CrossRef] [PubMed]

15. Torres-Giner, S.; Martinez-Abad, A.; Gimeno-Alcañiz, J.V.; Ocio, M.J.; Lagaron, J.M. Controlled delivery of gentamicin antibiotic from bioactive electrospun polylactide-based ultrathin fibers. Adv. Eng. Mater. 2012, 14, 112-122. [CrossRef]

16. Goetzendorf-Grabowska, B.; Polus, Z.; Kiwała, M.; Karaszewska, A.; Kamińska, I.; Mączka, I. Antibacterial air filter nonwovens modified by poly(lactide) microspheres containing triclosan. Fibres Text. East Eur. 2015, 23, 114-119.

17. Davachi, S.M.; Kaffashi, B.; Zamanian, A.; Torabinejad, B.; Ziaeirad, Z. Investigating composite systems based on poly L-lactide and poly L-lactide/triclosan nanoparticles for tissue engineering and medical applications. Mater. Sci. Eng. C Mater. Biol. Appl. 2016, 58, 294-309. [CrossRef]

18. Karaszewska, A.; Kamińska, I.; Kiwała, M.; Gadzinowski, M.; Gosecki, M.; Slomkowski, S. Preparation and properties of textile materials modified with triclosan-loaded polylactide microparticles. Polym. Adv. Technol. 2017, 28, 1185-1193. [CrossRef]

19. Yakub, G.; Toncheva, A.; Manolova, N.; Rashkov, I.; Danchev, D.; Kussovski, V. Electrospun polylactide-based materials for curcumin release: Photostability, antimicrobial activity, and anticoagulant effect. J. Appl. Polym. Sci. 2016, 133, 42940. [CrossRef]

20. Yakub, G.; Toncheva, A.; Manolova, N.; Rashkov, I.; Kussovski, V.; Danchev, D. Curcumin-loaded poly(L-lactide-Co-D,L-lactide) electrospun fibers: Preparation and antioxidant, anticoagulant, and antibacterial properties. J. Bioact. Compat. Polym. 2014, 29, 607-627. [CrossRef]

21. Medici, S.; Peana, M.; Nurchi, V.M.; Lachowicz, J.I.; Crisponi, G.; Zoroddu, M.A. Noble metals in medicine: Latest advances. Coord. Chem. Rev. 2015, 284, 329-350. [CrossRef]

22. Paladini, F.; Pollini, M.; Sannino, A.; Ambrosio, L. Metal-based antibacterial substrates for biomedical applications. Biomacromolecules 2015, 16, 1873-1885. [CrossRef]

23. Hoseinzadeh, E.; Makhdoumi, P.; Taha, P.; Hossini, H.; Stelling, J.; Kamal, M.A.; Ashraf, G. A review on nano-antimicrobials: Metal nanoparticles, methods and mechanisms. Curr. Drug. Metab. 2017, 18, 120-128. [CrossRef] [PubMed]

24. Rai, M.; Shegokar, R. Metal Nanoparticles in Pharma; Springer International Publishing: Cham, Switzerland, 2017.

25. Slavin, Y.N.; Asnis, J.; Häfeli, U.O.; Bach, H. Metal nanoparticles: Understanding the mechanisms behind antibacterial activity. J. Nanobiotechnol. 2017, 15, 65. [CrossRef] [PubMed]

26. Klebowski, B.; Depciuch, J.; Parlinska-Wojtan, M.; Baran, J. Applications of noble metal-based nanoparticles in medicine. Int. J. Mol. Sci. 2018, 19, 4031. [CrossRef] [PubMed] 
27. Sánchez-López, E.; Gomes, D.; Esteruelas, G.; Bonilla, L.; Lopez-Machado, A.L.; Galindo, R.; Cano, A.; Espina, M.; Ettecheto, M.; Camins, A.; et al. Metal-based nanoparticles as antimicrobial agents: An overview. Nanomaterials 2020, 10, 292. [CrossRef]

28. Wang, H.; Wei, Q.; Wang, X.; Gao, W.; Zhao, X. Antibacterial properties of PLA nonwoven medical dressings coated with nanostructured silver. Fiber Polym. 2008, 9, 556-560. [CrossRef]

29. Sun, Z.; Fan, C.; Tang, X.; Zhao, J.; Song, Y.; Shao, Z.; Xu, L. Characterization and antibacterial properties of porous fibers containing silver ions. Appl. Surf. Sci. 2016, 387, 828-838. [CrossRef]

30. Martínez-Abad, A.; Ocio, M.J.; Lagaron, J.M. Morphology, physical properties, silver release, and antimicrobial capacity of ionic silver-loaded poly(L-lactide) films of interest in food-coating applications. J. Appl. Polym. Sci. 2014, 131, 41001. [CrossRef]

31. Sójka-Ledakowicz, J.; Chruściel, J.J.; Kudzin, M.H.; Łatwińska, M.; Kiwała, M. Antimicrobial functionalization of textile materials with copper silicate. Fibres Text. East Eur. 2016, 24, 151-156. [CrossRef]

32. Virovska, D.; Paneva, D.; Manolova, N.; Rashkov, I.; Karashanova, D. Electrospinning/electrospraying vs. electrospinning: A comparative study on the design of poly(L-lactide)/zinc oxide non-woven textile. Appl. Surf. Sci. 2014, 311, 842-850. [CrossRef]

33. Toniatto, T.V.; Rodrigues, B.V.M.; Marsi, T.C.O.; Ricci, R.; Marciano, F.R.; Webster, T.J.; Lobo, A.O. Nanostructured poly (lactic acid) electrospun fiber with high loadings of $\mathrm{TiO}_{2}$ nanoparticles: Insights into bactericidal activity and cell viability. Mater. Sci. Eng. C Mater. Biol. Appl. 2017, 71, 381-385. [CrossRef]

34. Scopus Base. 287 Documents Results on Antibacterial \& Copper. Available online: https:/www-1scopus-1com10000147v00b6.han.p.lodz.pl/results/results.uri?numberOfFields=0\&src=s\&clickedLink=\&edit=\&editSaveSearch= \&origin=searchbasic\&authorTab=\&affiliationTab=\&advancedTab=\&scint=1\&menu=search\&tablin=\&searchterm1= Antibacterial+Copper\&field1=TITLE_ABS_KEY\&dateType=Publication_Date_Type\&yearFrom=Before+1960\&yearTo= Present\&loadDate $=7 \&$ documenttype $=$ All\&accessTypes $=$ All\&resetFormLink=\&st1 $=$ Antibacterial + Copper\&st2=\&sot $=$ b\&sdt=b\&sl=35\&s=TITLE-ABS-KEY\%28Antibacterial+Copper\%29\&sid=7456a8ca6e782e4746a73fa9c19ff5e7\&searchId= 7456a8ca6e782e4746a73fa9c19ff5e7\&txGid=271a497002bc4a7ce75a80cc22cd9308\&sort=plf-f\&originationType=b\&rr= (accessed on 25 August 2020).

35. Scopus Base. 5206 Documents Results on Antibacterial \& Metallic \& Copper. Available online: https://www-1scopus-1com10000147v00b7.han.p.lodz.pl/results/results.uri?numberOfFields=0\&src=s\&clickedLink=\&edit=\&editSaveSearch=\&origin= searchbasic\&authorTab=\&affiliationTab=\&advancedTab=\&scint=1\&menu=search\&tablin=\&searchterm1=antibacterial+ metallic+copper\&field1=TITLE_ABS_KEY\&dateType=Publication_Date_Type\&yearFrom=Before+1960\&yearTo=Present\& loadDate $=7 \&$ documenttype $=$ All\&accessTypes $=$ All\&resetFormLink=\&st $1=$ antibacterial + metallic + copper\&st2=\&sot=b\&sdt= b\&sl=44\&s=TITLE-ABS-KEY\%28antibacterial +metallic+copper\%29\&sid=f8209a25a17607eae8dff3520803ccdf\&searchId= f8209a25a17607eae8dff3520803ccdf\&txGid=19f07020ab9ba0c00ce0a023d21c5278\&sort=plf-f\&originationType=b\&rr= (accessed on 25 August 2020).

36. Durrant, P.J.; Durrant, B. Introduction to Advanced Inorganic Chemistry; Lonmgmans: London, UK, 1962; pp. 1211-1225.

37. Palmer, D.A.; Bénézeth, P. Solubility of Copper Oxides in Water and Steam. In Proceedings of the 14th International Conference on the Properties of Water and Steam (14th ICPWS) Water, Steam and Aqueous Solutions for Electric Power-Advances in Science and Technology, Kyoto, Japan, 29 August-3 September 2004; pp. 491-496.

38. Su, F.; Yao, K. Facile Fabrication of superhydrophobic surface with excellent mechanical abrasion and corrosion resistance on copper substrate by a novel method. ACS Appl. Mater. Interfaces 2014, 6, 8762-9787. [CrossRef] [PubMed]

39. Grass, G.; Rensing, C.; Solioz, M. Metallic copper as an antimicrobial surface. Appl. Environ. Microbiol. 2011, 77, 1541-1547. [CrossRef] [PubMed]

40. Radetzki, M. Seven thousand years in the service of humanity-The history of copper, the red metal. Resour. Policy 2009, 34, 176-184. [CrossRef]

41. Barceloux, D.G. Copper. Clin. Toxicol. 1999, 37, 217-230. [CrossRef]

42. Bradberry, S.M. Metals (cobalt, copper, lead, mercury). Medicine UK 2016, 44, 182-184. [CrossRef]

43. Giannousi, K.; Pantazaki, A.; Dendrinou-Samara, C. Copper-Based Nanoparticles as Antimicrobials. In Nanostructures for Antimicrobial Therapy: Nanostructures in Therapeutic Medicine Series; Elsevier Inc.: Amsterdam, The Netherlands, 2017; Volume 23, pp. 515-529. ISBN 9780323461511. 
44. Dalecki, A.G.; Crawford, C.L.; Wolschendorf, F. Copper and antibiotics: Discovery, modes of action, and opportunities for medicinal applications. Adv. Microb. Physiol. 2017, 70, 193-260. [CrossRef]

45. Chatterjee, A.K.; Chakraborty, R.; Basu, T. Mechanism of antibacterial activity of copper nanoparticles. Nanotechnology 2014, 25, 135101. [CrossRef]

46. Ingle, A.P.; Duran, N.; Rai, M. Bioactivity, mechanism of action, and cytotoxicity of copper-based nanoparticles: A review. Appl. Microbiol. Biotechnol. 2014, 98, 1001-1009. [CrossRef]

47. Vincent, M.; Duval, R.E.; Hartemann, P.; Engels-Deutsch, M. Contact killing and antimicrobial properties of copper. J. Appl. Microbiol. 2018, 124, 1032-1046. [CrossRef]

48. Bastos, C.A.P.; Faria, N.; Wills, J.; Malmberg, P.; Scheers, N.; Rees, P.; Powell, J.J. Copper nanoparticles have negligible direct antibacterial impact. NanoImpact 2020, 17, 100192. [CrossRef]

49. Khodashenas, B.; Ghorbani, H.R. Synthesis of copper nanoparticles: An overview of the various methods. Korean J. Chem. Eng. 2014, 31, 1105-1109. [CrossRef]

50. Camacho-Flores, B.A.; Martínez-Álvarez, O.; Arenas-Arrocena, M.C.; Garcia-Contreras, R.; Argueta-Figueroa, L.; de la Fuente-Hernández, J.; Acosta-Torres, L.S. Copper: Synthesis techniques in nanoscale and powerful application as an antimicrobial agent. J. Nanomater. 2015, 415238. [CrossRef]

51. Kobayashi, Y.; Yasuda, Y.; Morita, T. Recent advances in the synthesis of copper-based nanoparticles for metal-metal bonding processes. J. Sci. Adv. Mater. Devices 2016, 1, 413-430. [CrossRef]

52. Rafique, M.; Shaikh, A.J.; Rasheed, R.; Tahir, M.B.; Bakhat, H.F.; Rafique, M.S.; Rabbani, F. A review on synthesis, characterization and applications of copper nanoparticles using green method. Nano 2017, 12, 1750043. [CrossRef]

53. Fernández-Arias, M.; Boutinguiza, M.; del Val, J.; Riveiro, A.; Rodriguez, D.; Arias-Gonzalez, F.; Gil, J.; Pou, J. Fabrication and deposition of copper and copper oxide nanoparticles by laser ablation in open air. Nanomaterials 2020, 10, 300. [CrossRef]

54. Tan, X.Q.; Liu, J.Y.; Niu, J.R.; Liu, J.Y.; Tian, J.Y. Recent progress in magnetron sputtering technology used on fabrics. Materials 2018, 11, 1953. [CrossRef]

55. Segura, G.; Guzmán, P.; Zuñiga, P.; Chaves, S.; Barrantes, Y.; Navarro, G.; Asenjo, J.; Guadamuz, S.; Vargas, V.I.; Chaves, J. Copper deposition on fabrics by rf plasma sputtering for medical applications. J. Phys. Conf. Ser. 2015, 591, 012046. [CrossRef]

56. Kudzin, Z.H.; Kudzin, M.H.; Drabowicz, J.; Stevens, C.V. Aminophosphonic acids-phosphorus analogues of natural amino acids. Part 1: Syntheses of $\alpha$-aminophosphonic acids. Curr. Org. Chem. 2011, 15, 2015-2071. [CrossRef]

57. Drabowicz, J.; Jakubowski, H.; Kudzin, M.H.; Kudzin, Z.H. Nomenclature of aminoalkylphosphonic acids and derivatives. Evolution of the code system. Acta Biochim. Pol. 2015, 62, 139-150. [CrossRef]

58. Drabowicz, J.; Jordan, F.; Kudzin, M.H.; Kudzin, Z.H.; Stevens, C.V.; Urbaniak, P. Reactivity of aminophosphonic acids. Oxidative dephosphonylation of 1-aminoalkylphosphonic acids by aqueous halogens. Dalton Trans. 2016, 45, 2308-2317. [CrossRef]

59. Cypryk, M.; Drabowicz, J.; Gostynski, B.; Kudzin, M.H.; Kudzin, Z.H.; Urbaniak, P. 1-(Acylamino)alkyl-phosphonic acids-Alkaline deacylation. Molecules 2018, 23, 859. [CrossRef]

60. Kudzin, M.H.; Mrozińska, Z.; Walawska, A.; Sójka-Ledakowicz, J. Biofunctionalization of textile materials. 1. Biofunctionalization of poly(propylene) (PP) nonwovens fabrics by Alafosfalin. Coatings 2019, 9, 412. [CrossRef]

61. Kudzin, M.H.; Mrozińska, Z. Biofunctionalization of textile materials. 2. Antimicrobial modification of poly(lactide) (PLA) nonwoven fabrics by fosfomycin. Polymers 2020, 12, 768. [CrossRef] [PubMed]

62. EN 13758-1:2002. Textiles. Solar UV Protective Properties. Method of Test for Apparel Fabrics; International British Standards Institution: Geneva, Switzerland, 2002.

63. EN ISO 9237:1998. Textiles. Determination of the Permeability of Fabrics to Air; International Organization for Standardization: Geneva, Switzerland, 1998.

64. EN ISO 10319:2015. Geosynthetics-Wide-Width Tensile Test; International Organization for Standardization: Geneva, Switzerland, 2015.

65. The Perkin-Elmer Corporation. Analytical Methods for Atomic Absorption Spectroscopy; The Perkin-Elmer Corporation: Waltham, MA, USA, 1996; p. 46. Available online: www.perkinelmer.com (accessed on 3 July 2020).

66. ENISO 20645:2006. Textile Fabrics. Determination of Antibacterial Activity-Agar Diffusion Plate Test; International Organization for Standardization: Geneva, Switzerland, 2006. 
67. Jiang, L.; Wang, F.; Han, F.; Prinyawiwatkul, W.; No, H.K.; Ge, B. Evaluation of diffusion and dilution methods to determine the antimicrobial activity of water-soluble chitosan derivatives. J. Appl. Microbiol. 2012, 114, 956-963. [CrossRef] [PubMed]

68. Balouiri, M.; Sadiki, M.; Ibnsouda, S.K. Methods for in vitro evaluating antimicrobial activity: A review. J. Pharm. Anal. 2016, 6, 71-79. [CrossRef] [PubMed]

69. PN-EN 14119: 2005 point 10.5 (B2). Testing of Textiles-Evaluation of the Action of Microfungi_Visual Method; British Standards Institution: London, UK, 2005.

70. Kister, G.; Cassanas, G.; Vert, M. Effects of morphology, conformation and configuration on the IR and Raman spectra of various poly(lactic acid)s. Polymer 1998, 39, 267-273. [CrossRef]

71. Díaz-Visurraga, J.; Daza, C.; Pozo, C.; Becerra, A.; von Plessing, C.; García, A. Study on antibacterial alginate-stabilized copper nanoparticles by FT-IR and 2D-IR correlation spectroscopy. Int. J. Nanomed. 2012, 7, 3597-3612. [CrossRef]

72. Hemmati, S.; AhanyKamangar, S.; Ahmeda, A.; Zangeneh, M.M.; Zangeneh, A. Application of copper nanoparticles containing natural compounds in the treatment of bacterial and fungal diseases. Appl. Organomet. Chem. 2020, 34, 5465. [CrossRef]

(C) 2020 by the authors. Licensee MDPI, Basel, Switzerland. This article is an open access article distributed under the terms and conditions of the Creative Commons Attribution (CC BY) license (http://creativecommons.org/licenses/by/4.0/). 